Article

\title{
Direct Reduction of $\mathrm{Fe}, \mathrm{Ni}$ and $\mathrm{Cr}$ from Oxides of Waste Products Used in Briquettes for Slag Foaming in EAF
}

\author{
Arkadiy Davydenko, Andrey Karasev *, Björn Glaser@ and Pär Jönsson \\ Department of Materials Science and Engineering, KTH Royal Institute of Technology, SE-100 44 Stockholm, \\ Sweden; arkadyd@kth.se (A.D.); bjoerng@kth.se (B.G.); parj@kth.se (P.J.) \\ * Correspondence: karasev@kth.se; Tel.: +46-8-790-83-57
}

Received: 14 September 2019; Accepted: 14 October 2019; Published: 21 October 2019

\begin{abstract}
Environmental aspects and the sustainable manufacturing of steels require producers to pay more and more attention to the efficient utilization of materials and waste products during steelmaking. This study is focused on the evaluation of possibilities for the recovery of metals (such as $\mathrm{Fe}, \mathrm{Ni}$ and $\mathrm{Cr}$ ) from waste products used for slag foaming in the Electric Arc Furnace (EAF) process. Two types of industrial briquettes were produced by mixing mill-scale from the hot rolling of stainless steels with anthracite and pet-coke, respectively. Thereafter, an assessment of the metal reduction processes in briquettes at high temperatures $\left(1500{ }^{\circ} \mathrm{C}\right)$ was made by using laboratory thermo-gravimetric reduction experiments in an argon atmosphere. The amounts of metal, slag and gas obtained from the briquettes were estimated. In addition, the velocity and time for the removal of metal droplets from the liquid slag depending on the size of the metal droplets was estimated. It was found that up to $97 \%$ of metal droplets can be removed from the slag during the first $30 \mathrm{~min}$. Moreover, results showed that most of the $\mathrm{Cr}$, Ni and Fe (up to 93-100\%) can be reduced from oxides of these metals in briquettes at $1500{ }^{\circ} \mathrm{C}$. Moreover, the anthracite and pet-coke in the investigated briquettes have similar reduction capabilities. It was found that up to $330 \mathrm{~kg}$ of Fe, $28 \mathrm{~kg}$ of Ni and $66 \mathrm{~kg}$ of $\mathrm{Cr}$ per ton of added briquettes can be recovered from waste products by the industrial application of those briquettes for slag foaming in EAF.
\end{abstract}

Keywords: EAF; stainless steel; slag foaming; waste products; recycling; briquettes

\section{Introduction}

Today, the effective application of energy and recycling of waste products in the steel industry is becoming more and more important for the sustainable development of the steelmaking industry. The production of stainless steels includes many energy consuming stages such as scrap melting in the Electric Arc Furnace (EAF), melt decarburization in the Argon Oxygen Decarburizer (AOD), melt refining in a ladle, casting, rolling, etc. Moreover, many different types of wastes (such as mill-scale, dust, sludge, etc.) are formed during all these stages of steel production. For instance, an amount of 30 to $70 \mathrm{~kg}$ of mill-scale per ton of rolled products can be obtained just during a rolling operation, depending on the rolling process conditions [1]. This means that the amount of waste mill-scale from only the rolling process corresponds to on average $5 \%$ of the total production of stainless steels. According to the annual world production of stainless steels [2], on average 1.2-2.1 Mton/year of mill-scale is formed during the production of 25-42 Mton/year of stainless steels. Utilization of such residues is of significant interest to the steel industry in Sweden. According to the Swedish Steel Association Jernkontoret [3], residue products such as slag, sludge, dust and mill-scale generally are sold or reused internally, otherwise they are sent to landfills. 
Currently, the EAF process is one of the most energy consuming process used for the production of stainless steel. A more effective utilization of electric energy can be achieved by using slag foaming in the EAF process. It is well known that the foamed slag in the EAF can significantly help to decrease heat loss, the wear of furnace refractory and dust emissions. Slag foaming during the EAF process can be obtained by the additional formation of $\mathrm{CO}$ and $\mathrm{CO}_{2}$ gas bubbles in the slag, created by the addition of different foaming agents such as waste metal oxides [4-9], $\mathrm{CaCO}_{3}[4,5], \mathrm{Ca}\left(\mathrm{NO}_{3}\right)_{2}\left(\mathrm{H}_{2} \mathrm{O}\right)_{2}[5,10]$, $\mathrm{CaC}_{2}$ [11], $\mathrm{NiO}+\mathrm{C}$ [5], $\mathrm{FeSi}$ [12], doping agents ( $\left.\mathrm{Fe}, \mathrm{C}, \mathrm{Si}, \mathrm{Mn}, \mathrm{O}_{2}\right)$ [13,14] and $\mathrm{MgCO}_{3}$ [15]. The addition of foaming materials into the furnace slag is usually carried out by injection and/or by addition of special briquettes. In general, these briquettes contain both reducible oxides as well as a reducing agent such as carbon. This mixture of oxides and carbon should provide gas generation at the high temperatures $\left(\geq 1500^{\circ} \mathrm{C}\right)$ required for slag foaming to occur during the EAF process. According to thermodynamic considerations, such oxides containing iron, nickel and chromium can be reduced by carbon at temperatures of $\geq 1500{ }^{\circ} \mathrm{C}$. The mill-scale from stainless steel production, which contains mostly a mixture of these oxides, can be used as the main component for manufacturing the foaming briquettes. Thus, the application of such briquettes can be an efficient way for simultaneously slag foaming in the EAF and recycling waste products obtained from the steelmaking industry.

Some researchers in recent years have demonstrated that it is possible to utilize such briquettes with mill-scale in BOF [16] and the EAF steelmaking process [17]. In addition, researchers have reported that it is possible to create slag foaming in the EAF by such briquettes [7,18]. Furthermore, Lopez et al. [19] and Yang et al. [20] have reported that it is possible to use recycled metal oxides from the briquettes to create slag foaming in the EAF. However, some aspects regarding the feasibility and kinetics of recovering valuable metals $(\mathrm{Fe}, \mathrm{Ni}$ and $\mathrm{Cr}$ ) from the briquettes with mill-scale during slag foaming in the EAF need to be studied more in detail.

The aim of this article is a laboratory investigation the possibilities of recovering $\mathrm{Fe}, \mathrm{Ni}$, and $\mathrm{Cr}$ oxides by different reducing agents in slag foaming briquettes. Different reduction agents were mixed with mill-scale into briquettes used for EAF slag foaming. Moreover, the briquettes' capacity for slag foaming under ideal conditions was estimated with a view to trials under industrial conditions. Slag foaming under industrial conditions with these types of briquettes has been studied previously [21].

\section{Materials and Methods}

Two types of briquettes, which can be used in the EAF to improve the foaming of the furnace slag, were produced on an industrial scale. The composition recipes for both types of briquettes have been described in a previous study [22]. Anthracite and pet-coke waste was used as a source of carbon in the Type $\mathrm{A}$ and Type $\mathrm{C}$ briquettes, respectively. Additional raw materials used for briquette production were lignin $(\sim 5 \%)$, slaked lime $\left(\mathrm{Ca}(\mathrm{OH})_{2}, \sim 3 \%\right)$, limestone $\left(\mathrm{CaCO}_{3}, \sim 5 \%\right)$ and mill-scale $(70-72 \%)$ formed during the hot rolling of stainless steels. Here and below the amounts of components are given in weight percentage. The average chemical compositions of the obtained industrial briquettes are given in Table 1. The typical photographs of the obtained industrial briquettes and briquette samples used in the laboratory trials are shown in Figure 1. The briquettes were manufactured by crushing, raw materials screening, mixing and hot-pressing operations.

Table 1. Average chemical compositions of different industrial briquettes (in $w \mathrm{t} \%$ ).

\begin{tabular}{ccccccccccc}
\hline Briquette & $\mathrm{C}$ & $\mathrm{FeO}_{\mathbf{x}}$ & $\mathbf{N i O}$ & $\mathrm{Cr}_{2} \mathrm{O}_{3}$ & $\mathbf{S i O}_{2}$ & $\mathbf{A l}_{2} \mathrm{O}_{3}$ & $\mathbf{M g O}$ & $\mathbf{C a O}$ & $\mathbf{M n O}$ & $\mathbf{S}$ \\
\hline A (anthracite) & 21.72 & 47.56 & 3.34 & 11.36 & 3.77 & 1.12 & 0.40 & 8.56 & 1.29 & 0.88 \\
\hline $\mathrm{C}$ (pet-coke) & 20.16 & 51.26 & 3.44 & 10.81 & 2.96 & 1.16 & 0.35 & 7.53 & 1.31 & 1.01 \\
\hline \multicolumn{8}{c}{ * Source of carbon in briquette. }
\end{tabular}




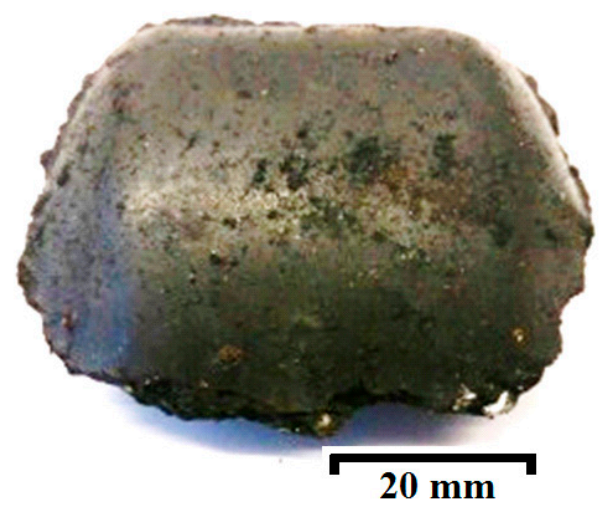

(a)

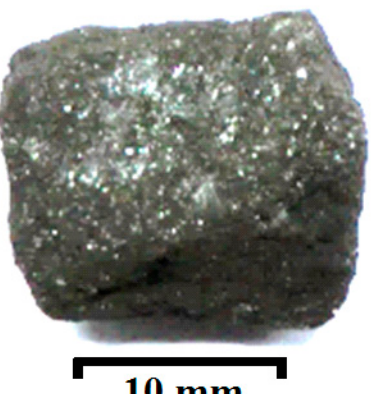

$10 \mathrm{~mm}$

(b)

Figure 1. Typical images of an industrial briquette (a) and a briquette sample used in the thermo-gravimetric reduction (TGR) experiments (b).

An evaluation of reduction processes in briquettes at high temperatures was made by using laboratory thermo-gravimetric reduction (TGR) experiments. Schematic illustrations of the equipment setup and main operations of the TGR experiments are shown in Figure 2. The TGR experiments were performed in a resistance furnace with a controlled argon gas $(99.99 \% \mathrm{Ar})$ flow $(0.1 \mathrm{~L} / \mathrm{min})$. The initial weight of the briquette samples (Figure $1 \mathrm{~b}$ ) was in the range of 7 to $8 \mathrm{~g}$. After heating the reaction zone (RZ) of the furnace up to $1500{ }^{\circ} \mathrm{C}$, an $\mathrm{Al}_{2} \mathrm{O}_{3}$ crucible with a briquette sample was lowered for $70 \mathrm{~s}$ from the cold zone (CZ) of the furnace $\left(<50^{\circ} \mathrm{C}\right)$ into the reaction zone (RZ). After $30 \mathrm{~min}$ of holding in the reaction zone, the basket with the crucible was lifted up to the cold zone of the furnace and kept there to cool the sample. The reduction of the sample weight due to gas generation during the experiment was measured continuously by using a digital balance. Moreover, after each TGR experiment, the metal and slag, which were formed during reduction processes in the briquette sample, were crushed, separated by using a strong magnet, and weighed. In total, three TGR experiments were carried out for each type of briquette using the same experimental conditions. Detailed descriptions of the performed TGR experiments are given in a previous article [22].

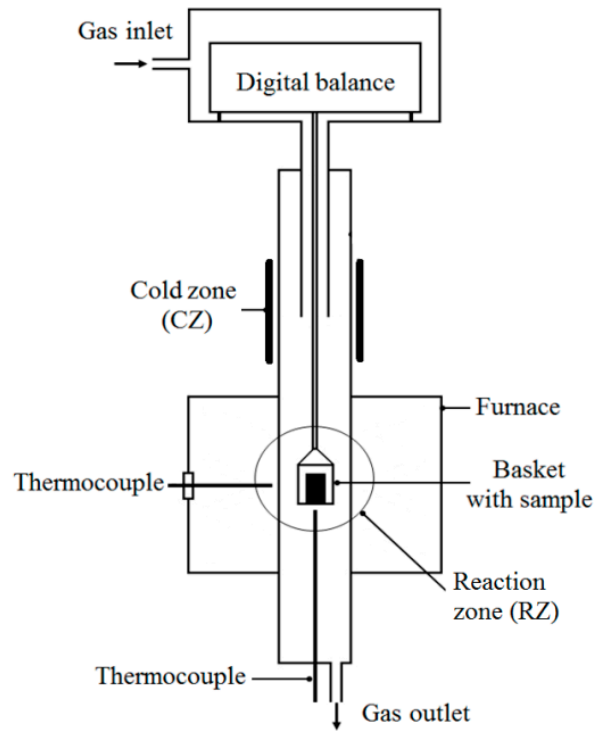

(a)

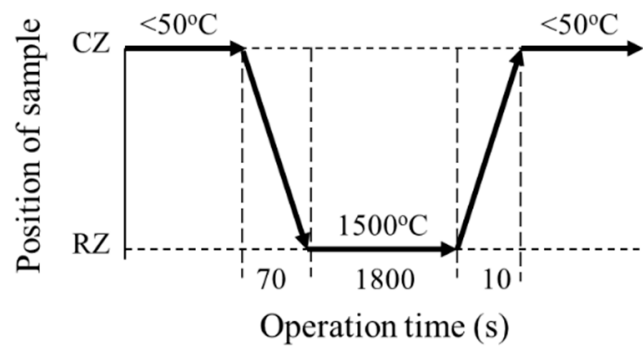

(b)

Figure 2. Schematic illustrations of the equipment setup (a) and the main operational description of the TGR experiment (b). 
Samples taken before and after completion of the TGR experiments were dry polished and investigated by using a scanning electron microscope (SEM) equipped with an energy-dispersive spectroscopy (EDS) analyzer. The average compositions of the metal and slag phases were determined at least three times in different zones by using the area scan mode of EDS.

The removal of formed metal droplets from the unstirred slag melt was evaluated by using the following version of Stokes law:

$$
v_{(\mathrm{MD})}=\frac{2 \mathrm{~g}}{9} \cdot \frac{\rho_{(\mathrm{MD})}-\rho_{(\text {slag })}}{\eta_{(\text {slag })}} \cdot\left(\frac{\mathrm{D}_{(\mathrm{MD})}}{2}\right)^{2}
$$

where $v_{(\mathrm{MD})}$ is the sinking velocity of the liquid metal droplet in the unstirred liquid slag having a Reynolds number $<1$; $\mathrm{g}$ is the gravitational acceleration $\left(=9.81 \mathrm{~m} / \mathrm{s}^{2}\right) ; \rho_{(\mathrm{MD})}$ and $\rho_{(\mathrm{slag})}$ are the densities of the metal droplets and slag melt. The parameter $\eta_{(\text {slag })}$ is the dynamic viscosity of the liquid slag and $\mathrm{D}_{(\mathrm{MD})}$ is the diameter of the formed metal droplets.

\section{Results and Discussion}

To evaluate the repeatability of data obtained during the TGR experiments, three trials for each type of briquette were done using the same experimental conditions. Typical changes of the sample weight during the TGR experiments are shown in Figure 3 for experiments $C 1, C 2$ and $C 3$ with Type $\mathrm{C}$ briquette samples. It can be seen that deviations in the results obtained in the $\mathrm{C} 1, \mathrm{C} 2$ and $\mathrm{C} 3$ experiments varied from $0.3 \%$ up to $2.5 \%$ during a holding time of $30 \mathrm{~min}$. A similar tendency was observed in the experiments with Type A briquette samples. Therefore, it was concluded that the obtained results demonstrated a very good repeatability of the given TGR experimental conditions for both types of industrial briquettes.

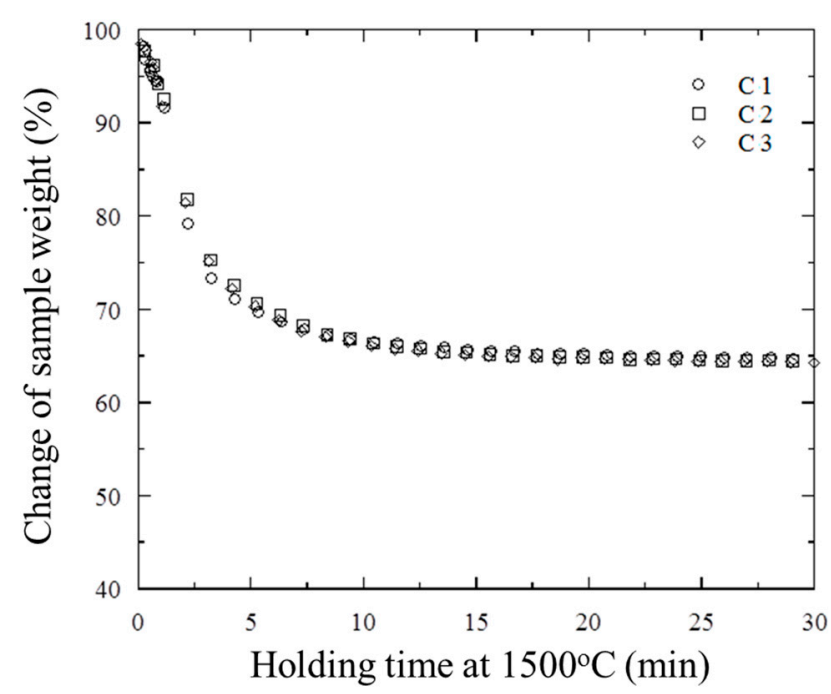

Figure 3. Typical changes of the weight of briquette samples over time during the TGR experiments.

The fast decrease of the sample weight during the first 5 to $7 \mathrm{~min}$ of the holding time of the samples in the hot zone can be explained by the intensive reductions of $\mathrm{Fe}, \mathrm{Ni}$ and $\mathrm{Cr}$ oxides by carbon in the anthracite and pet-coke in the briquettes at $1500{ }^{\circ} \mathrm{C}$. This occurs due to the following reactions (Equations (2)-(3)):

$$
\begin{gathered}
\mathrm{Fe}_{2} \mathrm{O}_{3}+3 \mathrm{C}=2 \mathrm{Fe}+3 \mathrm{CO}(\mathrm{g}) \\
\mathrm{NiO}+\mathrm{C}=\mathrm{Ni}+\mathrm{CO}(\mathrm{g})
\end{gathered}
$$




$$
\mathrm{Cr}_{2} \mathrm{O}_{3}+3 \mathrm{C}=2 \mathrm{Cr}+3 \mathrm{CO}(\mathrm{g})
$$

This reduction of the $\mathrm{Fe}, \mathrm{Ni}$ and $\mathrm{Cr}$ oxides leads to the formation of metal droplets of different sizes. Typical SEM images of metal droplets observed in the slag after the TGR experiments are shown in Figure 4. It was found that the observed diameter of the metal droplets, $\mathrm{D}_{(\mathrm{MD})}$, varied widely in the range of $2 \mu \mathrm{m}$ up to $\sim 2.0 \mathrm{~mm}$.

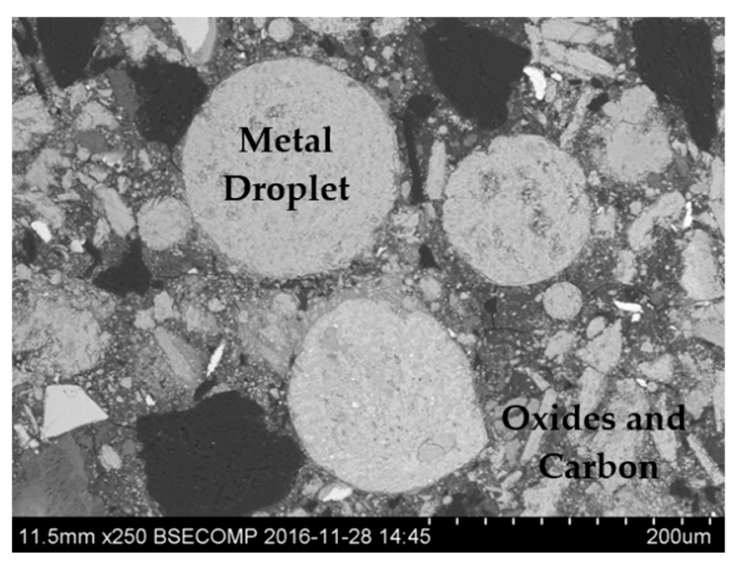

(a)

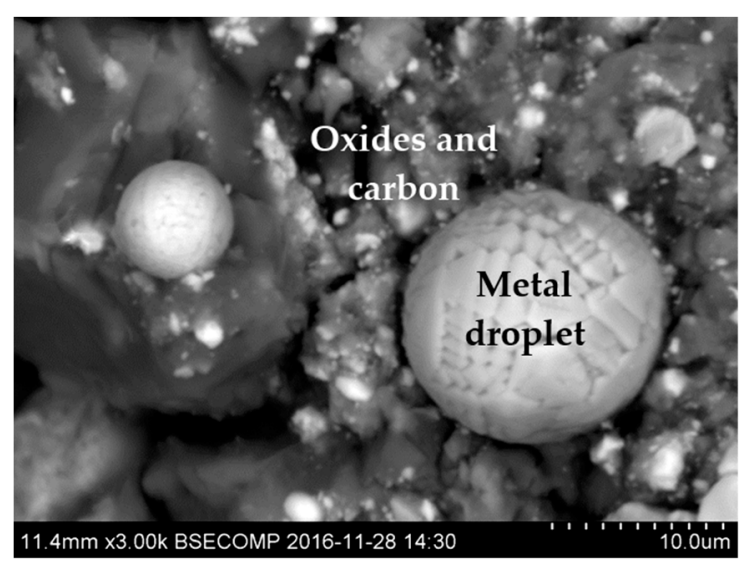

(b)

Figure 4. SEM images of different metal droplets (a) and (b) observed in the slag after completion of the TGR experiments.

By assuming that only the inner components of the briquettes were involved in these reactions and that the formed gas is $\mathrm{CO}$, the decrease of the sample weight during the TGR experiments was found to correspond to the weight of the formed $\mathrm{CO}$ gas. Thus, the briquette samples at $1500{ }^{\circ} \mathrm{C}$ form a gas ( $34-36 \%$ from the initial weight of briquette sample), a reduced metal $(\sim 48-51 \%)$ and a remaining slag $(\sim 15-17 \%)$. The amounts of gas, metal and slag formed from the briquette sample during the TGR experiments are shown in Figure 5. It can be seen that the amounts of gas, metal and slag obtained during all TGR experiments are very similar for the different briquette samples. For instance, deviations in the weight of the metal part measured after the TGR experiments from the average value for each type of briquette are smaller than $1 \%$. These results once more confirm the repeatability of the TGR experiments for current experimental conditions.

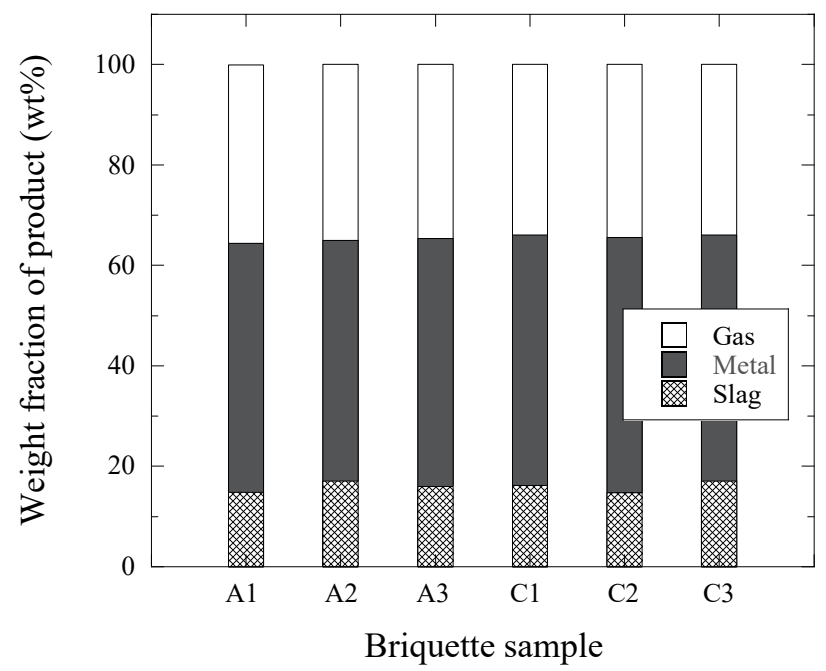

Figure 5. Amounts of gas, metal and slag formed from different briquettes during the TGR experiments at $1500{ }^{\circ} \mathrm{C}$. 
Tables 2 and 3 show the average compositions of the metal and slag after the completed TGR experiments obtained from the SEM-EDS analysis. It should be noted that the content of $\mathrm{Al}_{2} \mathrm{O}_{3}$ in the slag increases significantly during experimentation due to some erosion of the $\mathrm{Al}_{2} \mathrm{O}_{3}$ crucible. However, the influence of an additional amount of $\mathrm{Al}_{2} \mathrm{O}_{3}$ eroded from the crucible walls on the final composition of slag formed from a briquette was eliminated by using mass balance calculations. As follows from Tables 2 and 3, the compositions of the obtained metals and slags are typical for the production of stainless steels.

Table 2. Average compositions (SEM-EDS analysis) of the metals obtained from different briquettes after completion of the TGR experiments (in $w \mathrm{t} \%$ ).

\begin{tabular}{ccccccc}
\hline Briquette & Fe & Cr & Ni & C & Al & S \\
\hline A & 71.15 & 13.93 & 6.12 & 7.55 & 0.09 & 1.15 \\
C & 69.95 & 14.27 & 6.01 & 8.78 & 0.15 & 0.84 \\
\hline
\end{tabular}

Table 3. Average compositions (SEM-EDS analysis) of the slags obtained from different briquettes after completion of the TGR experiments (in $w \mathrm{t} \%$ ).

\begin{tabular}{ccccccccc}
\hline Briquette & $\mathrm{CaO}$ & $\mathrm{SiO}_{2}$ & $\mathrm{Al}_{\mathbf{2}} \mathbf{O}_{3}$ & $\mathbf{M n O}$ & $\mathbf{M g O}$ & $\mathrm{Cr}_{2} \mathbf{O}_{3}$ & $\mathbf{F e O}$ & $\mathbf{S}$ \\
\hline $\mathrm{A}$ & 56.70 & 17.19 & 11.77 & 5.12 & 2.69 & 3.96 & 0.49 & 2.09 \\
$\mathrm{C}$ & 57.35 & 16.52 & 12.67 & 4.03 & 3.94 & 1.03 & 0.00 & 4.46 \\
\hline
\end{tabular}

The amount of metal, which was recovered from the briquettes during the TGR experiments, was evaluated by using the mass balance and stoichiometric calculations described in previous work [22,23]. According to the obtained results, the amounts of $\mathrm{Cr}$ extracted from the briquettes with anthracite and pet-coke are $93-94 \%$ and $93-99 \%$, respectively. The amounts of extracted Fe and $\mathrm{Ni}$ are almost $100 \%$ for both types of briquettes. Moreover, it should be pointed out that most (84-86\%) Fe, Ni and $\mathrm{Cr}$ was reduced during the first 5 to $7 \mathrm{~min}$ of holding at $1500^{\circ} \mathrm{C}$. Also, the anthracite and pet-coke showed similar good reductant properties during the extraction of these metals from the oxides in the briquettes. A relatively lower extraction amount of $\mathrm{Cr}(93-99 \%)$ in comparison to $\mathrm{Fe}$ and $\mathrm{Ni}(\sim 100 \%)$ may be explained by a slower reduction rate of chromium oxides by carbon agents in the briquettes at the given temperature.

The metal droplets, which formed from briquettes at high temperatures, can lower from the liquid EAF slag due to significant differences in the densities of the metal droplets $\left(\sim 7150 \mathrm{~kg} \cdot \mathrm{m}^{-3}\right)$ and slag melt. The values of the removing velocity of the liquid metal droplet, $v(\mathrm{MD})$, in the unstirred

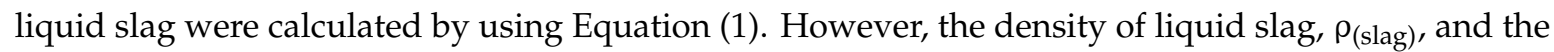
dynamic viscosity of the liquid EAF slag, $\eta_{\text {(slag) }}$, varied in relatively wide ranges depending on slag composition (basicity of slag, $\mathrm{Cr}_{2} \mathrm{O}_{3}$ content, etc.) and temperature. For instance, the $\rho_{\text {(slag) }}$ values for liquid stainless steelmaking slags containing $2-15 \% \mathrm{Cr}_{2} \mathrm{O}_{3}$ varied from 3066 to $3410 \mathrm{~kg} \cdot \mathrm{m}^{-3}[15,21]$. In this study, a $\rho_{(\text {slag) }}$ value of $3200 \mathrm{~kg} \cdot \mathrm{m}^{-3}$ was used for the evaluation of the sinking velocities of the liquid metal droplets in the liquid slag. The $v_{(\mathrm{MD})}$ values were calculated for different sizes of metal droplets in low viscosity slags (LVS, $\left.\eta_{(\mathrm{LVS})}=0.3-1.0 \mathrm{~Pa} \cdot \mathrm{s}\right)$ and in high viscosity slags (HVS, $\eta_{\text {(HVS) }}=1.0-5.0$ Pa.s) $[15,21]$. Moreover, the time required for the separation of different metal droplets from the liquid slag, $\tau_{(\mathrm{MD})}$, was also estimated for the slag layer in the furnace. The slag thickness was assumed to be $100 \mathrm{~mm}$, which is close to values used in industrial practice. The obtained results are shown in Figure 6. 


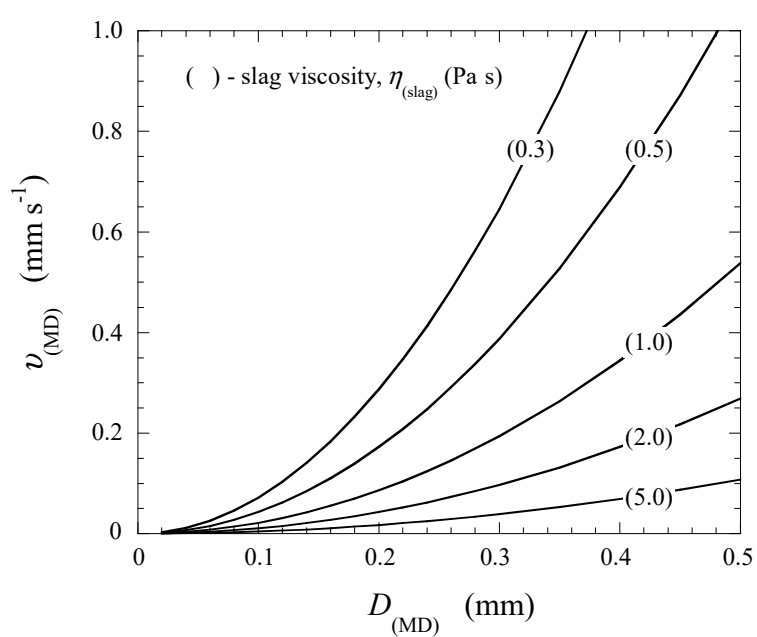

(a)

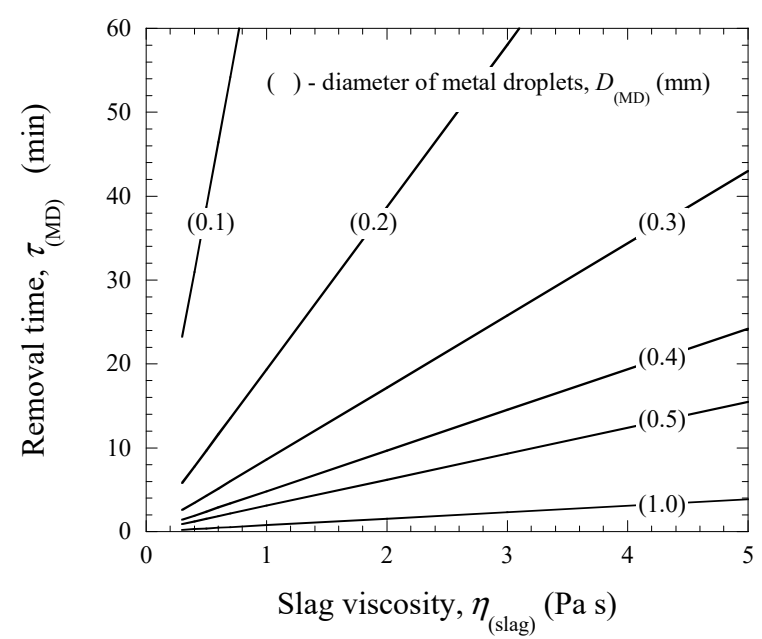

(b)

Figure 6. Calculated velocity, $v_{(\mathrm{MD})}$, and time, $\tau_{(\mathrm{MD})}$, for the removal of metal droplets from the liquid slag depending on the size of metal droplets, $\mathrm{D}_{(\mathrm{MD})}(\mathbf{a})$, and the slag viscosity, $\eta_{(\mathrm{slag})}(\mathbf{b})$.

It was found that all droplets larger than $0.3 \mathrm{~mm}$ can be separated completely from LVS slags at around $9 \mathrm{~min}$ because the minimum values of $v_{(\mathrm{MD})}$ for $\mathrm{D}_{(\mathrm{MD})}=0.3 \mathrm{~mm}$ are almost $0.2 \mathrm{~mm} \cdot \mathrm{s}^{-1}$. However, the metal droplets with a size of smaller than $0.3 \mathrm{~mm}$ can only be partially removed. This is due to the fact that the $\tau_{(\mathrm{MD})}$ value varies from 3 to $77 \mathrm{~min}$ for $\mathrm{D}_{(\mathrm{MD})}=0.29$ and $0.1 \mathrm{~mm}$, respectively. In this case, the removal velocities of those metal droplets only reached values of between 0.6 and $0.02 \mathrm{~mm} \cdot \mathrm{s}^{-1}$, respectively. These calculated data agreed well with the experimental results obtained in this study. Most of the metal droplets, which were observed in the slag samples after the TGR experiments, have a diameter of smaller than $0.3 \mathrm{~mm}$. In the HVS slags $\left(\eta_{(\mathrm{HVS})}=1.0-5.0 \mathrm{~Pa} \cdot \mathrm{s}\right)$, the metal droplets with $\mathrm{D}_{(\mathrm{MD})}=0.5-1.0 \mathrm{~mm}$ can be removed completely from the slag during 1 to $16 \mathrm{~min}$ depending on the size of the metal droplets and the viscosity of the slags. The separation times $\tau_{(\mathrm{MD})}$ for other size ranges of droplets varied from 3 to $43 \mathrm{~min}$ for $\mathrm{D}_{(\mathrm{MD})}=0.3-0.5 \mathrm{~mm}$ and from 9 to $390 \mathrm{~min}$ for $\mathrm{D}_{(\mathrm{MD})}=0.1-0.3 \mathrm{~mm}$. This means that most droplets in the size range of 0.3 to $0.5 \mathrm{~mm}$ and only a small part of the droplets in the size range of 0.1 to $0.3 \mathrm{~mm}$ can be removed from the HVS slags during the EAF process. However, it should be noted that foaming EAF slags can have significantly lower densities compared to the slag density used for calculations in this study. This would make it easier to transfer an overwhelming majority of metal droplets from the slag phase to the metal phase.

The results also showed that the overwhelming majority of the recovered metal (about 93-97\%) after the TGR experiments was observed at the bottom of the crucible in the form of a large metal tablet (3.4-3.6 g of metal). Moreover, only 3-8\% of the recovered metal was distributed in the form of metal droplets in the slag. Apparently, the small metal droplets can grow faster by merging together to form larger droplets. Thereafter, they can easily be removed from the liquid slag due to an increased sinking velocity. However, it should be noted that intensive stirring of an EAF slag during foaming can significantly change the behavior of the metal droplets recovered from the briquettes as well as their removal from the slag to the steel bath.

During the industrial production of stainless steel in the EAF (85 ton capacity), 1-3 ton of these briquettes can be added to form a foaming slag. In this case, the amounts of $\mathrm{Fe}, \mathrm{Ni}$ and $\mathrm{Cr}$ extracted from the given briquettes reached values of approximately 330, 28 and $66 \mathrm{~kg}$ per ton of added briquettes, respectively. This could save a significant amount of expensive ferroalloys and alloys used during the production of stainless steels. In addition, this could contribute to the recycling of waste products from the stainless steel industry as well as improve slag foaming during the EAF process.

Future trends in the studying of mill-scale based briquettes applied for slag foaming in the EAF steelmaking process could include a wider kinetic study at various temperatures and gas atmospheres in order to research reduction process at different time steps. 


\section{Conclusions}

The recovery of $\mathrm{Fe}, \mathrm{Ni}$ and $\mathrm{Cr}$ from oxides present in briquettes, which can be used for slag foaming in the Electric Arc Furnace (EAF) during stainless steel production, was investigated in laboratory thermo-gravimetric reduction (TGR) experiments. The following conclusions were obtained based on the results obtained from mass balance calculations, thermo-gravimetric experiments and energy-dispersive spectroscopy investigations:

1. The main products, which were obtained during a reduction of $\mathrm{Fe}_{2} \mathrm{O}_{3}, \mathrm{NiO}$ and $\mathrm{Cr}_{2} \mathrm{O}_{3}$ from rolling mill-scale with anthracite and pet-coke in the given briquettes, are metals (totally $47-50 \mathrm{wt} \%$ of $\mathrm{Fe}, \mathrm{Ni}$ and $\mathrm{Cr})$, gas (33-35 $\mathrm{wt} \%)$ and slag (15-17 $\mathrm{wt} \%)$.

2. Up to $95-97 \%$ of metal droplets recovered from the briquettes can be removed from the slag in $30 \mathrm{~min}$ of the TGR experiments. Only $3-5 \%$ of the recovered metal was distributed in the slag in the form of metal droplets having diameters of mostly smaller than $0.3 \mathrm{~mm}$.

3. Almost $100 \%$ of $\mathrm{Fe}$ and $\mathrm{Ni}$ were extracted from the given briquettes at $1500{ }^{\circ} \mathrm{C}$. Moreover, approximately $93-99 \%$ of $\mathrm{Cr}$ were extracted from these briquettes at the given conditions of the TGR experiments. By using 1 to 3 ton of such briquettes for slag foaming in the EAF, up to 330, 28 and $66 \mathrm{~kg}$ of $\mathrm{Fe}, \mathrm{Ni}$ and $\mathrm{Cr}$, respectively, were recovered from 1 ton of added briquettes.

Author Contributions: Conceptualization, A.D. and A.K.; methodology, A.D. and A.K.; validation, A.D., A.K. and P.J.; investigation, A.D. and A.K.; resources, B.G and P.J.; writing-original draft preparation, A.D. and A.K.; writing—review and editing, A.K. and P.J.; supervision, A.K., B.G. and P.J.; project administration, P.J.; funding acquisition, P.J.

Funding: This research received no external funding.

Conflicts of Interest: The authors declare no conflict of interest.

\section{References}

1. Esezobor, D.; Rostovsky, V.; Tunik, O.; Baidinet, O. Directions for the Organization of Waste less Metallurgical Processes. Technical Report Deposited with Ukraine Technical Information. Translation from Russian language, Ukraine. 1993. Available online: https://www.google.com.tw/url?sa=t\&rct=j\&q= \&esrc $=$ s\&source=web\&cd=1\&ved=2ahUKEwi0_8eHp6zlAhVJCqYKHYTgDpMQFjAAegQIARAB\&url= http \%3A\%2F\%2F196.45.48.50\%2Fopendocnew.php\%3Fsno\%3D18081\%26doctype\%3Dpdf\%26docname\% 3D18081\%26doctitle\%3DDirections-for-the-Organization-of-Waste-less-Metallurgical-Processes\%3F. \&usg=AOvVaw2T31ZqrJf1xOGbtEU0oAMx (accessed on 20 October 2019).

2. International Stainless Steel Forum (ISSF). World Steel in Figures; ISSF: Brussels, Belgium, 2016.

3. Jernkontoret Handbook. Stålindustrin Gör mer än Stål Handbok För Restprodukter; Jernkontoret: Stockholm, Sweden, 2012.

4. Massucci, P.; Capodilupo, D.; Brascugli, G. Foaming Slags for Stainless Steel Smelting in the Electric Arc Furnace. In Proceedings of the 51st Electric Furnace Conference, Washington, DC, USA, 7-10 November 1993.

5. Fruehan, R.J.; Kerr, J.J. Additions to Generate Foam in Stainless Steelmaking. Metall. Mater. Trans. B 2004, 35, 643-650. [CrossRef]

6. Kerr, J.J.; Fruehan, R.J. Foamability of Stainless Steelmaking Slags in an EAF. Iron Steelmak. 2002, $29,45-52$.

7. Reichel, J.; Rose, L.; Kempken, J.; Damazio, M.A.; Carvalho, R.G.; Loss, H.B.; Pinto, E.M.; Dutra, J.R.; Karbowniczek, M. EAF-Foamy Slag in Stainless Steel Production. New Extremely Efficient Technology. Easy to Handle and Cost Efficient. Arch. Met. Mater. 2008, 53, 1-7.

8. Görnerup, M.; Jacobsson, H. Foaming slag practice in electric stainless steelmaking. Iron Steelmak. 1998, 25, 59-66.

9. Juhart, M.; Peter, M.; Koch, K.; Lamut, J.; Rozman, A. Foaming Behaviour of Slags From Stainless Steelmaking in the Electric Arc Furnace. Stahl Eisen 2001, 121, 35-44.

10. Tuvnes, P.; Engh, T.A. Foaming of stainless steel slags in EAFs using calcium nitrate. Iron Steelmak. 2003, 43-47. 
11. Parker, M.L.; Robinson, S.W. EAF Slag Conditioning Using Calcium Carbide: A Cost Benefit Approach. Iron Steel Technol. 2005, 2, 25-31.

12. Lee, Y.E.; Görnerup, M.; Klevan, O.S. Slag Foaming in Electric Furnace Stainless Steel Melting. In Proceedings of the 57th Electric Furnace Conference, Pittsburgh, PA, USA, 14-16 November 1999; pp. 413-422.

13. Görnerup, M. Metallurgical Product. U.S. Patent 6.689.189 B1, 10 February 2004.

14. Klevan, O.S.; Görnerup, M. Continuous Slag Composition Control and Sufficient Gas Generation-key factors to a successful foaming slag practice in electric stainless steelmaking. In Proceedings of the 8th Electric Furnace Conference and 17th Process Technology, Orlando, FL, USA, 8-12 May 2000.

15. Mapelli, C.; Mombelli, D.; Barella, S.; Trezzi, P.; Ferrari, G.; Cagni, C. Experimental trials and theoretical background about foaming, slag refractory interaction and feasibility of rude magnesium carbonate injection as foaming agent and its use for EAF refractory protection. La Metal. Italaina 2014, 5, 29-36.

16. Kumar, D.S.; Sah, R.; Sekhar, V.R.; Vishwanath, S.C. Development and use of mill scale briquettes in BOF. Ironmak. Steelmak. 2016, 44, 134-139. [CrossRef]

17. Bagatini, M.C.; Zymal, V.; Osorio, E.; Antonio Cezar Faria Vilela, C.F. Scale Recycling Through Self-Reducing Briquettes to Use in EAF. ISIJ Int. 2017, 12, 2081-2090. [CrossRef]

18. Mostafaee, S. A Study of EAF High-Chromium Stainless Steelmaking Slags Characteristic and Foamability. Ph.D. Thesis, KTH Royal Institute of Technology, Stockholm, Sweden, May 2011.

19. Lopez, F.A.; Lopez-Delgado, A. Enhancement of Electric Arc Furnace Dust by Recycling to Electric Arc Furnace. J. Environ. Eng. 2002, 128, 1169-1174. [CrossRef]

20. Yang, Q.; Holmberg, N.; Björkman, B. EAF Smelting Trials of Waste-Carbon Briquettes at Avesta Works of Outokumpu Stainless AB for Recycling Oily Mill Scale Sludge from Stainless Steel Production. Steel Res. Int. 2009, 80, 422-428.

21. Davydenko, A.; Karasev, A.; Lindstrand, G.; Jönsson, P. Investigation of Slag Foaming by Additions of Briquettes in the EAF during Stainless Steel Production. Steel Res. Int. 2015, 86, 146-153. [CrossRef]

22. Davydenko, A.; Mostafaee, S.; Karasev, A.; Jönsson, P. Characterization of Briquettes Used for Slag Foaming in the EAF during Stainless Steel Production. Steel Res. Int. 2015, 86, 137-145. [CrossRef]

23. Mostafaee, S.; Magnusson, M. Styrning och Övervakning av Slaggbildningsförloppet i Ljusbågsugn. Slutrapport TO 23-136/JK23028; Jernkontoret: Stockholm, Sweden, 2011. 